(C) 2015

\author{
Степаненков Г. В., аспірант
}

(науковий керівник - доктор сільськогосподарських наук, професор П. В. Писаренко)

Полтавська державна аграрна академія

\title{
ВПЛИВ ЯКОСТІ ПИТНОЇ ВОДИ НА СТАН ЗДОРОВ'Я НАСЕЛЕННЯ ПОЛТАВСЬКОЇ ОБЛАСТІ В 2001-2012 РОКАХ
}

\section{Рецензент - доктор сільськогосподарських наук. професор М. Я. Шевніков}

У статті розглядається вплив якості питної води Полтавської області на стан здоров'я населення, а також представлені результати даного дослідження. Отримані результати подані у вигляді наведених графіків і обрахованих коефіцієнтів корелячії. Графіки наведені як для загальної захворюваності по області, так $і$ для двох найбільш розповсюджених груп захворювань (хвороби систем кровообігу, хвороби кістково-м'язової системи і сполучної тканини). Доведено, щуо якість питної води в області суттєво впливає на стан здоров'я людей. Зроблені відповідні висновки загального характеру.

Ключові слова: питна вода, здоров'я населення.

Постановка проблеми. Вода є одним із головних ресурсів, без якого неможливе життя на Землі. I людина - не виняток. Оскільки наше тіло складається на 80 \% із води. Закономірно, що, коли в процесі виробництва благ забруднюються водні ресурси, то здоров'я тих людей, які споживають цю воду, починає погіршуватися. Особливо гострою ця проблема є для країн із недостатнім поверхневим водозабезпеченням.

Аналіз останніх досліджень і публікацій, у яких започатковано розв'язання проблеми. В останні роки на Полтавщині спостерігається тенденція до збільшення використання води $[3,6]$. Так, у 2012 році було піднято 248,4 млн м ${ }^{3}$ води, 3 яких 77,06 млн м ${ }^{3}$ підземної [6]. Водночас кількість населення в області поступово зменшується [1].

Разом із тим якість води у річках та водотоках $\epsilon$ незадовільною (вода у 53 \% відібраних пробах характеризувалася як «дуже брудна» [8]), погіршується також якість грунтових і підземних вод, які, в основному, використовують для водопостачання та питних цілей $[3,8]$, і не лише сільське населення, а й підприємства у містах, хоча останні добувають глибинну воду, яка є доволі чистою. Так, 50 \% населення області для питних потреб використовує грунтові води, якість якої дуже різниться в залежності від місця і глибини свердловини. Основними забруднювачами поверх- невих вод $є$ БСК 5 та біогенні елементи, а грунтових та підземних (залежно від району) - загальне залізо, фтор, азот амонійний та нітрати, загальна жорсткість [2, 3]. Динаміка забруднення грунтових вод нітрат-іонами $є$ вкрай актуальною темою, оскільки в Полтавській області коефіцієнт розораності земель становить 0,75 , і в гонитві за прибутком аграрії часто 3 надлишком використовують мінеральні добрива. Наявність нітратіонів у воді питного призначення - вкрай негативний фактор, оскільки наявність цих іонів у воді питного призначення викликає розлади в роботі кишково-шлункового тракту, серцевої та нервової систем й особливо небезпечним є для дітей віком до одного року, в яких викликає метгемоглобінемію. Ця проблема досліджувалася різними авторами $[4,5,7]$.

Метою даного дослідження було дослідити вплив якості питної води на стан здоров'я населення Полтавської області.

Завданням було обрахувати коефіцієнти кореляції та побудувати графіки впливу якості питної води на стан здоров'я населення Полтавщини.

Матеріали і методи досліджень. Матеріали для даного дослідження були взяті в обласному управлінні статистики в області та обласній санітарноепідеміологічній станції $[1,2]$. Для вирішення поставленої задачі були використані систематичні, аналітичні, статистичні методи дослідження.

Результати досліджень. Проблема здоров'я населення є вкрай важливою, оскільки кількість населення в області за досліджуваний період (з 2001 по 2012 рр.) скоротилася на 152,9 тис. і має спадну динаміку. Але водночас зменшується і загальна кількість захворювань. Динаміка наведена на рисунку 1. Як бачимо, кількість населення в області поступово зменшується і має яскраво виражену тенденцію до подальшого скорочення.

Водночас зменшується й загальна кількість захворювань, що є позитивним фактором. Тому для більш правильного проведення розрахунків використовувалася відносна величина - кількість випадків на 100 тисяч жителів. 


\section{СТОРІНКА МОЛОДОГО ВЧЕНОГО}

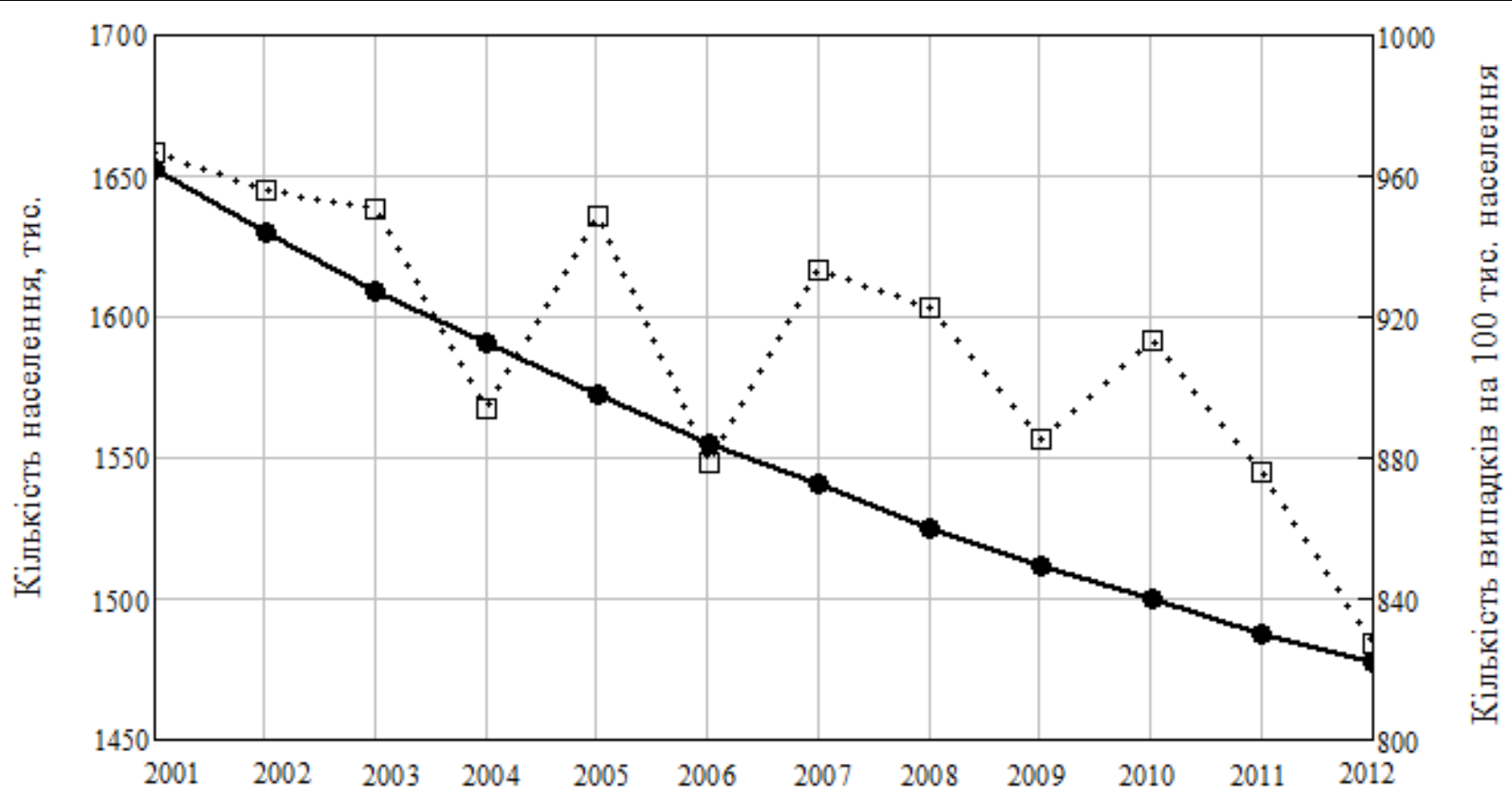

Роки

\section{- - Кількість населення області}

$\succeq+\square$ Захворюванність на 100 тис. населення

\section{Рис. 1. Динаміка кількості населення області та первинної захворюваності (за даними обласного статичного управління області) з 2001 по 2012 роки}

Матеріалами досліджень були дані взяті в Полтавській обласній санепідемстанції [2] та в управлінні статистики в області [1]. На основі цих даних проведений аналіз впливу стану питної води на стан здоров'я населення області, були побудовані відповідні графіки й розраховані коефіцієнти кореляції Пірсона за відомою формулою:

$$
\mathrm{P}=\frac{\sum(\mathrm{x}-\overline{\mathrm{x}}) \cdot(\mathrm{y}-\overline{\mathrm{y}})}{\sqrt{\sum(\mathrm{x}-\overline{\mathrm{x}})^{2} \cdot \sum(\mathrm{y}-\overline{\mathrm{y}})^{2}}},
$$

або вбудованою функцією пакету Microsoft Office Excel = КОРРЕЛ (масив 1; масив 2) або = PEARSON (масив 1; масив 2).

Для спрощення оцінювання якості води використовувався інтегральний показник, що $є$ середнім арифметичним між невідповідністю проб щодо чинного законодавства, відібраних у мережах централізованого водопостачання (за санітарно-хімічним і бактеріологічним показниками) та децентралізованого (за санітарно-хімічним і бактеріологічним показниками) за 12 років [2].

Отриманні результати наведені нижче.

На рисунку 2 наведена динаміка невідповід- ності якості води чинному (державні санітарні правила i норми) законодавству (середнє по області).

Як бачимо, спостерігається тенденція до покращання якості води децентралізованого водопостачання й певне незначне погіршення централізованого (останнє пов'язане зі зношенням водопровідних мереж).

На наступному графіку (рис. 3) наведено порівняння інтегрального показника якості води в області та первинної захворюваності.

Як бачимо на графіку, криві досить різні, залежність не спостерігається; також це підтверджує i низьке значення коефіцієнта кореляції $(\mathrm{r}=0,29)$. Це легко пояснити: 44 \% $(4808,5$ тис. iз 10952,7 тис. випадків за весь досліджуваний період) від загальної кількості захворювань становлять хвороби органів дихання, що не пов'язані з якістю питної води.

Тому вони були нами виключені, як такі, що заважають дослідженню; разом із тим була виключена і друга група - травми, отруєння та деякі інші наслідки зовнішніх причин. Після цього був заново порахований коефіцієнт кореляції та побудований графік, який представлений на рисунку 4. 


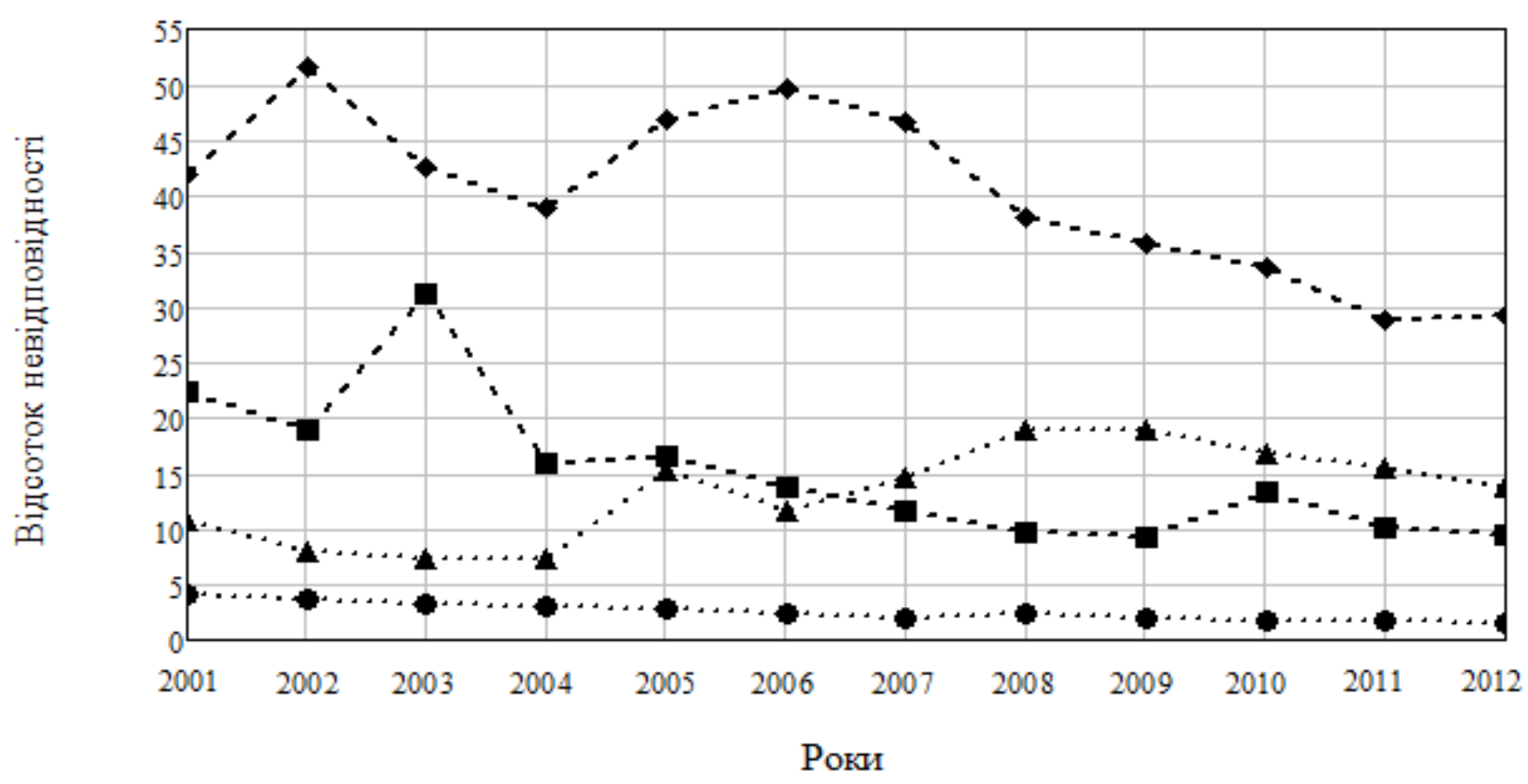

- - Децентралізоване водопостачання (санітарно-хімічні показники)

- - Децентралізоване водопостачання (бактереологічні показники)

*. Централізоване водопостачання (санітарно-хімічні показники)

- Централізоване водопостачання (бактереологічні показники)

Рис. 2. Динаміка якості води в області

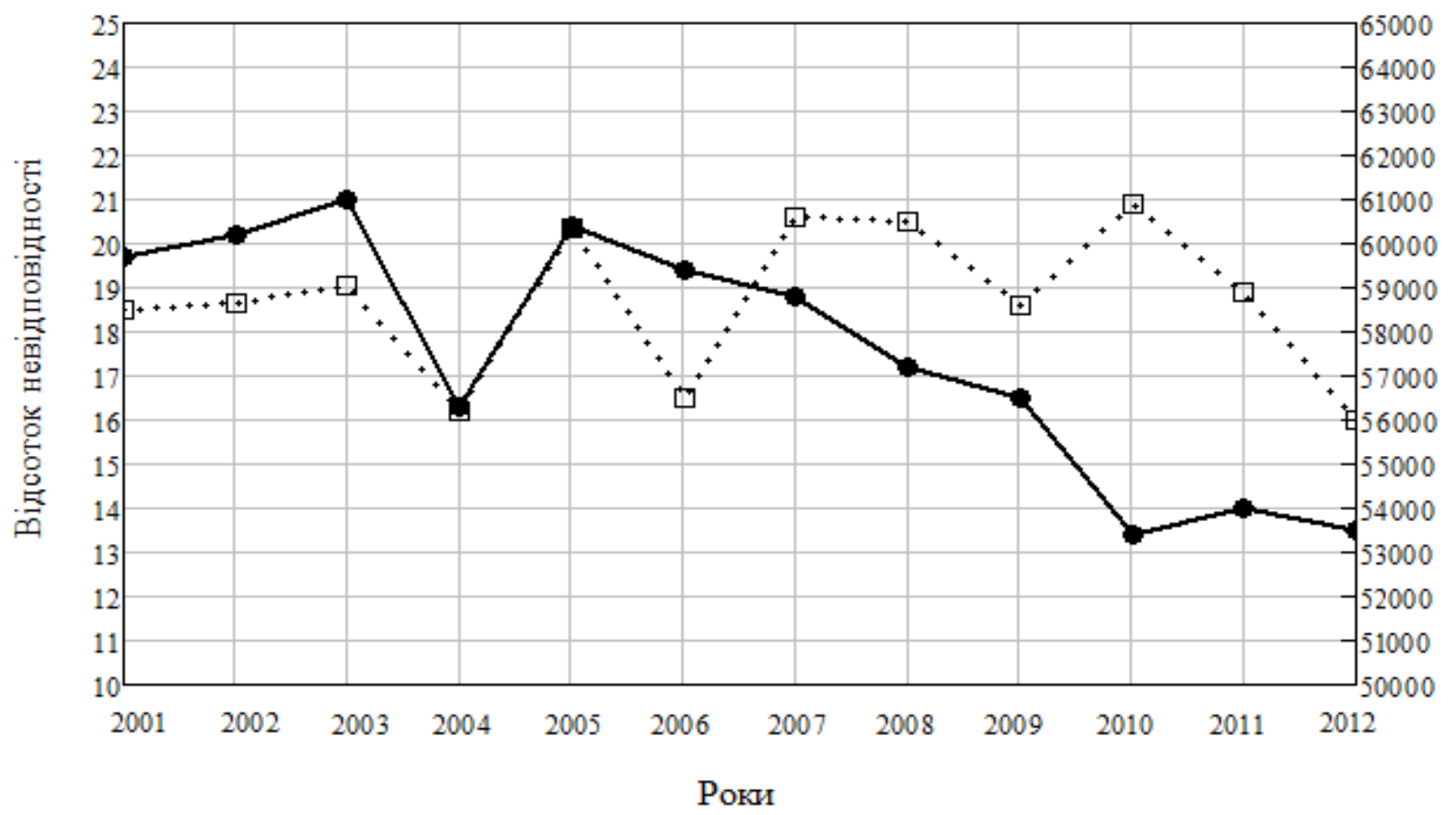

Ннтегральний показник якості води

$\succeq$ ๑ Захворюванність на 100 тис. населення

Рис. 3. Порівняння інтетрального показника якості питної води та первинної захворюваності 


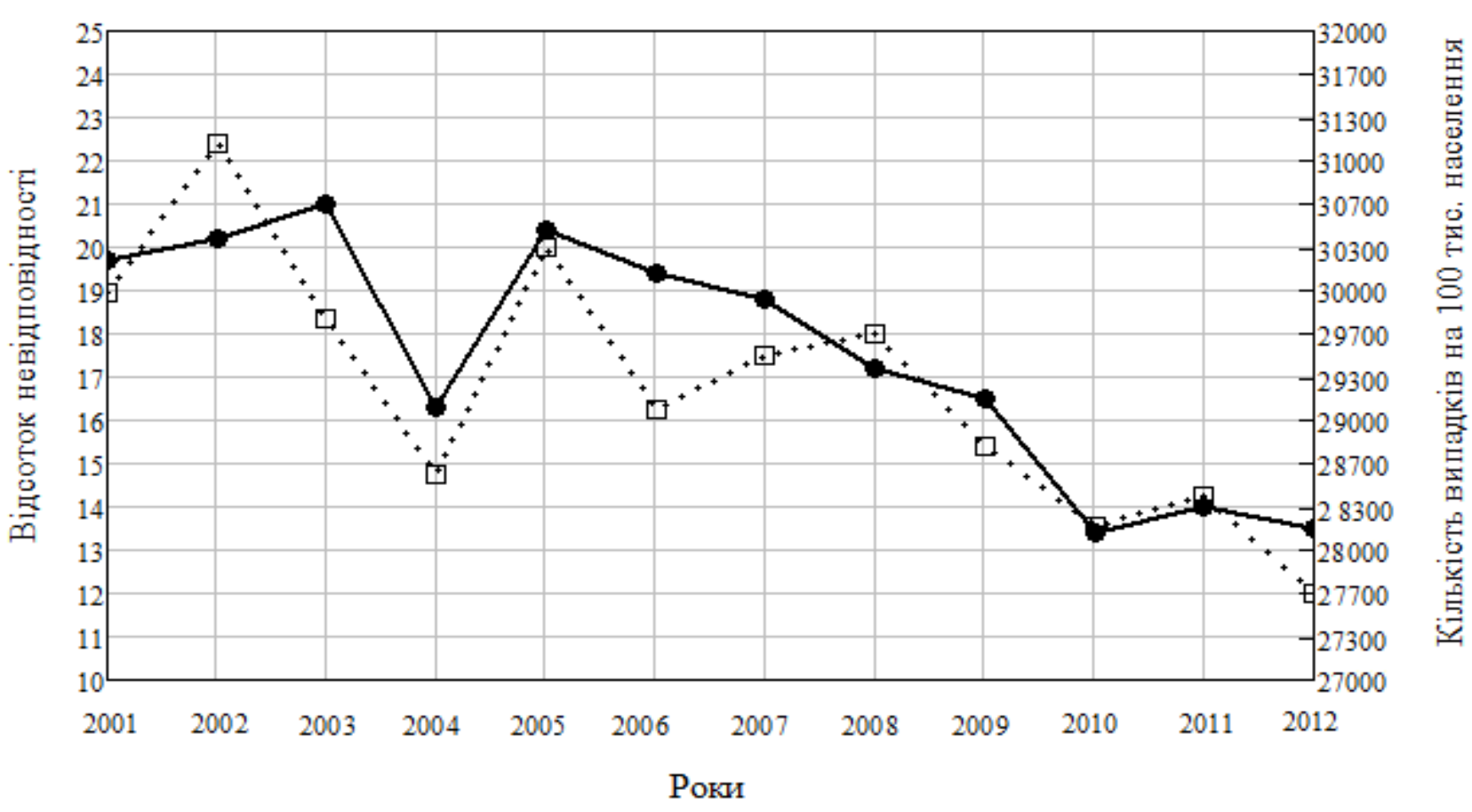

Інтегральний показник якості води

$\succeq$ ๑ Захворюванність на 100 тис. населення

Рис. 4. Порівняння інтетрального показника якості питної води і первинної захворюваності (без хвороб органів дихання, травм, отруєнь та інших наслідків зовнішніх причин)

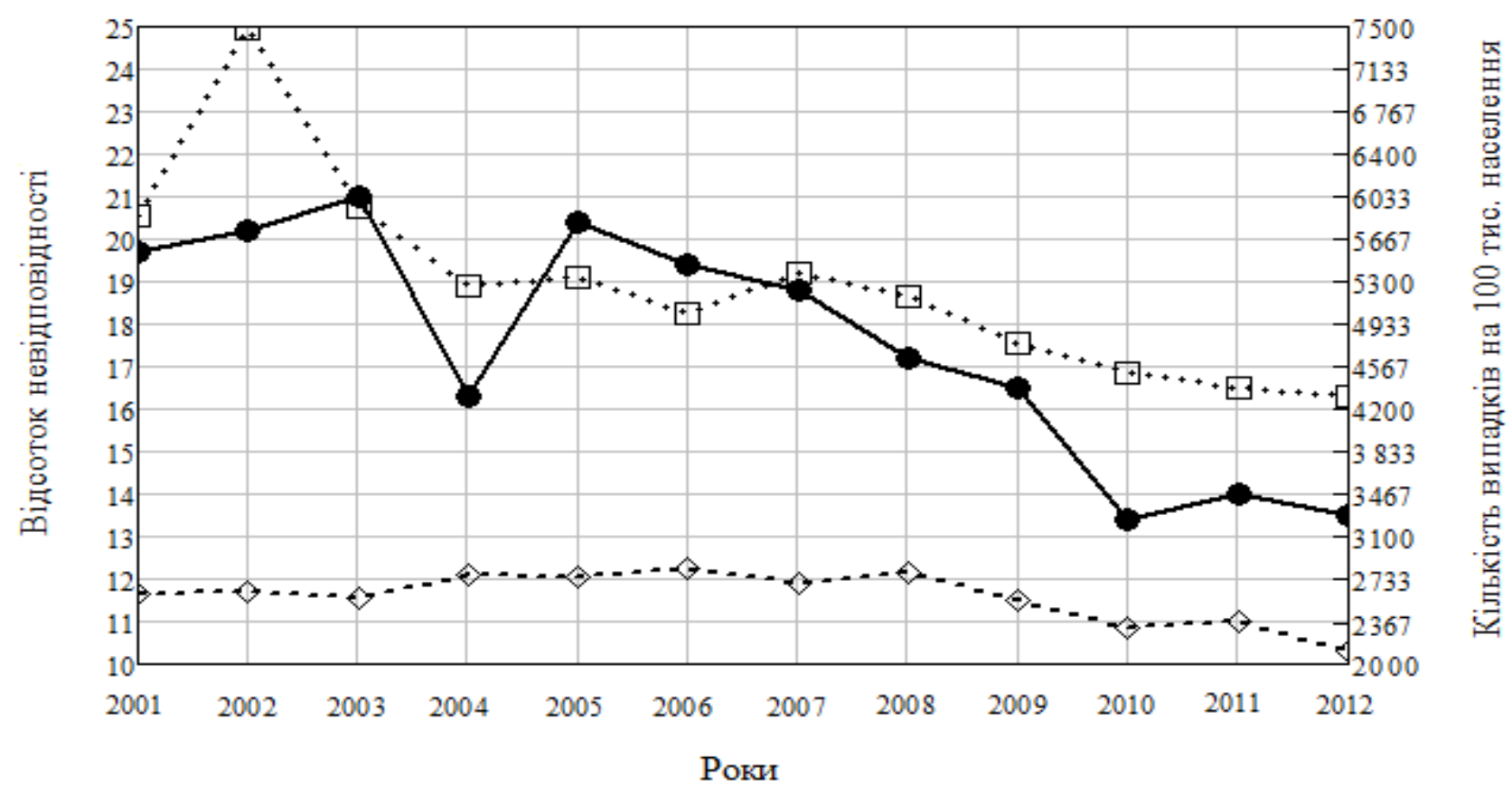

Інтегральний показник яккості води

$\bigoplus \boxminus$ Хвороби систем кровообігу

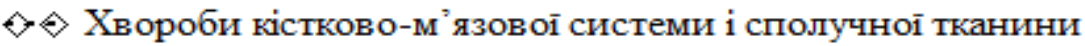

Рис. 5. Порівняння інтетрального показника якості питної води та деяких груп захворювань 


\section{СТОРІНКА МОЛОДОГО ВЧЕНОГО}

Як бачимо з даного графіка, після того як хвороби органів дихання і травми не враховувалися, криві стали досить подібними; крім того підтверджується високе значення коефіцієнта кореляції $(\mathrm{r}=0,86)$, що вказує на високий рівень кореляції. Це свідчить про те, що якість питної води суттєво впливає на стан здоров'я населення області. Позитивним $\epsilon$ той факт, що спостерігається тенденція щодо покращання якості води разом зі зменшенням кількості захворювань.

Підраховані також і коефіцієнти кореляції для окремих груп захворювань. Далі наведені хвороби, для яких дані коефіцієнти набули досить високих значень: хвороби систем кровообігу, хвороби кістково-м'язової системи і сполучної тканини $-\mathrm{r}=0,76$ i $\mathrm{r}=0,66$ відповідно. Особливу увагу слід звернути на захворювання систем кровообігу, оскільки це за чисельністю становить другу групу захворювань - 8 \% (990,7 тис. iз 10952,7 тис. випадків за весь досліджуваний період). Інша група захворювань також займає високе третє місце - 482,3 тисяч випадків. Отримані графіки наведені вище (рис. 5).

Як бачимо, криві доволі схожі, що підтвер-

\section{БІБЛІОГРАФІЯ}

1. Дані обласного статичного управління в Полтавській області з 2001 по 2012 роки [Електронний ресурс]. - Режим доступу : http://www. poltavastat.gov.ua/

2. Дані обласної санітарно-епідеміологічної станції в Полтавській області з 2001 по 2012 роки.

3. Екологічний атлас Полтавщини : навч. видання ; [за ред Ю. С. Голіка, В. А. Барановського, О. Е. Ілляш]. - Полтава : Полтавський літератор, 2007. - $128 \mathrm{c}$.

4. Коваль В.В. Динаміка забруднення вод сільськогосподарського призначення нітратами в умовах Полтавської області / В.В.Коваль, В. О. Наталочка, С. К. Ткаченко, О. В. Міненко // Вісник Полтавської державної аграрної академії. 2011. - №2. - C. 32-36.

5. Мосейчук А. А. Оцінка якості питної води в джерелах децентралізованого водопостачання Полтавської області / А. А. Мосейчук, І. А. Бойко // Вісник Полтавської державної аграрної академiї. - 2011. - №4. - С. 12-17. джує досить високе значення коефіцієнта кореляції.

\section{Висновки:}

1. Кількість населення Полтавської області поступово зменшується і має спадну динаміку.

2. Первинна захворюваність населення зменшується, як абсолютна, так і відносна (у перерахунку на 100 тис. жителів).

3. Якість питної води в області також поступово покращується, особливо це стосується децентралізованого водопостачання.

4. Спостерігається суттєва кореляція між якістю питної води та первинною захворюваністю в області, на що вказує коефіцієнт кореляції $(\mathrm{r}=0,86)$.

5. Основними хворобами в області $є$ хвороби органів дихання, на другому місці - хвороби систем кровообігу, а на третьому - хвороби кістковом'язової системи і сполучної тканини.

6. Існує залежність між якістю питної води й окремими групами хвороб - це хвороби систем кровообігу, хвороби кістково-м'язової системи і сполучної тканини $\mathrm{r}=0,76$ i r $=0,66$ відповідно.

6. Національна доповідь про якість питної води та стан питного водопостачання в Україні у 2012 році [Електронний ресурс]. - Режим доступу : http://minregion.gov.ua/discussion/proektnacionalnoyi-dopovidi-pro-yakist-pitnoyi-vodi-ta-stanpitnogo-vodopostachannya-v-ukrayini-u-2012-roci/.

7. Нітратне забруднення джерел питної води в Україні: дослідження ВЕГО «МАМА-86» за 2001-2008 р. [Електронний ресурс]. - К., 2009. 16 c. - Режим доступу : http://www.ecotoilet.com. ua/UserFiles/Images/Content/content/instructions/Hiтратне забруднення джерел питної води в Україні.pdf.

8. Регіональна програма охорони довкілля, раціонального використання природних ресурсів та забезпечення екологічної безпеки з урахуванням регіональних пріоритетів Полтавської області на 2012-2015 роки (програма «Довкілля 2015») [Електронний ресурс]. - Режим доступу : http://www.eco-poltava.gov.ua/vikprogd.htm. 